\title{
Effect of housing system during pregnancy on reproductive parameters of sows
}

\author{
[Efeito do sistema de alojamento durante a gestação sobre os parâmetros reprodutivos de porcas] \\ J.E.G.N. Perini ${ }^{1}$, C.B. Ludtke ${ }^{2}$, C.B. Tanure ${ }^{1}$, L. Seixas ${ }^{1}$, V.Peripolli ${ }^{3 *}$, C. McManus ${ }^{4}$ \\ ${ }^{1}$ Faculdade de Agronomia e Medicina Veterinária - Universidade de Brasília - Brasília, DF \\ ${ }^{2}$ Associação Brasileira de Criadores de Suínos - Brasília, DF \\ ${ }^{3}$ Instituto Federal Catarinense - Campus Araquari - Araquari, SC \\ ${ }^{4}$ Instituto de Ciências Biológicas - Universidade de Brasília - Brasília, DF
}

\begin{abstract}
The aim of this study was to evaluate the reproductive performance of sows in individual stalls (Stall) or group-housed into groups on days 3 to 5 (Pen5) or 38 to 42 (Pen42) after breeding. The reproductive data was collected from the operating system of the farm establishing the average of the weekly performances of the sows that gave birth, for four years, except for the Pen5 system, which was evaluated for three years. Statistical analyses were performed using SAS®, using MIXED (for quantitative traits), NPAR1WAY (for categorical traits) and LOGISTIC (binomial traits) procedures, using sows as a repeated measure. Sows in Stall system had piglets with higher birth weight them sows in the group-housed system $(\mathrm{P}<0.05)$, however the piglets born alive, total piglets weaned, average litter weight, and duration of farrowing were lower in this system than in the group-housed $(\mathrm{P}<0.0001)$. There was no difference between Pen5 and Stall systems for gestation period and mummified piglets. The Pen42 system had a higher percentage of mummified piglets and a shorter gestation period, when compared Pen5 and Stall systems $(\mathrm{P}<0.0001)$, and similar results to the Pen5 system for duration of farrowing, piglets born alive, stillbirths, total piglets weaned, average litter weight and birth weight $(\mathrm{P}<0.0001)$.
\end{abstract}

Keywords: animal welfare, farrowing, husbandry system, pig, reproduction

\section{RESUMO}

O objetivo deste estudo foi avaliar a performance reprodutiva de matrizes suínas alojadas individualmente (Individual) ou em grupos, nos dias 3 a 5 (Grupo 5) ou 38 a 42 (Grupo 42) após a inseminação. Os dados reprodutivos foram coletados do sistema operacional da granja, estabelecendo-se a média dos desempenhos semanais das matrizes que pariram por semana, durante quatro anos, exceto para o sistema Grupo 5, que foi avaliado por três anos. A análise estatística foi realizada com SAS ${ }^{\circledR}$, usando-se os procedimentos MIXED (para variáveis quantitativas), NPARIWAY (para variáveis categóricas) e LOGISTIC (para variáveis binomiais), tendo a matriz como uma medida repetida. As matrizes no sistema Individual tiveram leitões com maior média de peso ao nascer do que as matrizes nos sistemas de alojamento em grupo ( $P<0,05)$, porém os leitões nascidos vivos, o total de leitões nascidos, o peso médio da leitegada e a duração do parto foram menores no sistema Individual do que nos sistemas de alojamento em grupo $(P<0,0001)$. Não houve diferença entre os sistemas Grupo 5 e Individual para o tempo de duração da gestação e o número de leitões mumificados. O sistema Grupo 42 apresentou maior porcentagem de leitões mumificados e menor período de gestação, quando comparado aos sistemas Grupo 5 e Individual ( $P<0,0001)$, e resultados semelhantes ao sistema Grupo 5 para duração do parto, leitões nascidos vivos, natimortos, total de leitões desmamados, peso médio da leitegada e peso ao nascer $(P<0,0001)$.

Palavras-chave: bem-estar animal, parto, reprodução, sistema de criação, suíno

Recebido em 31 de janeiro de 2020

Aceito em 17 de junho de 2020

*Autor para correspondência (corresponding author)

E-mail: vanessa.peripolli@hotmail.com 


\section{INTRODUCTION}

Large-scale swine production in collective housing systems is a recent practice and there are many doubts as to the best management practices to adopt within this system, as well as the system interference on reproductive parameters. Environmental variables such as thermal comfort and diseases as well as management such as feeding and employee training can negatively influence reproductive efficiency (Pandorfi et al., 2011) and studies are needed to elucidate the best time to remove the sows from insemination stalls and reintroduce them to the group, minimizing losses in reproductive performance (Stevens et al., 2015).

The indication of the Directive 2008/120/EC of the European Union to reduce the risk of abortion or embryonic absorption is rearing pregnant sows in collective pens during the period comprising the four weeks after insemination, and the seven days before the expected date of farrowing (The Council..., 2009). This is important, as these first weeks are crucial to development and embryonic survival (Kranendonk et al., 2007; Knox, 2014).

Gestation lasts on average $114 \pm 4$ days and is divided into egg, embryonic and fetal phases (Alvarenga et al., 2013). In the embryonic phase, or organogenesis, the implantation of the embryos occurs equitably in the uterine horns due to the migration of the eggs until their nesting that occurs around 17 to 24 days after the fertilization. During this period, the most important tissues, organs and systems of the organism are formed (Alvarenga et al., 2013). Mixing or regrouping the sows during this phase can lead to an increase in embryonic mortality and, consequently, a reduction in fertility or litter size (Dron et al., 2014). Therefore, group-housing should occur before or after this period.

The prolonged activation of the stress axis, based on elevated cortisol levels, may inhibit or impair reproductive success via disruption of the reproductive axis, which may affect fertilization and implantation due to sustained, elevated cortisol levels that disrupt reproductive processes (Salak-Johnson, 2017). Sows reared in the Stall system suffer from chronic stress that can affect their reproductive performance, however, sows reared group-housed also have moments of negative interactions that generate acute stress, and consequently, decrease their reproductive performance. In this regard, Van Wettere et al. (2008) studied the effect of group-housing during the first four weeks or at the first 10 days of gestation. The pregnancy rate was similar for both treatments, with a mean of $95 \%$.

The number of embryos present on the 26th day of gestation, as well as embryo survival rates were not affected by the housing system, showing that individual housing of sows soon after their first insemination did not improve embryo survival. Therefore, studies that evaluate the possibility of group-housing the sows, immediately after the insemination, are necessary in order to be sure of the efficiency of this handling and to better orient the layouts of the new facilities of modern pig farms. The aim of this study was to determine whether measures of reproductive performance differed between sows housed individually throughout gestation or group-housed into groups on days 3 to 5 or 38 to 42 after insemination.

\section{MATERIALS AND METHODS}

Animal care procedures throughout the study followed protocols approved by the Ethics Committee for Animal Use (CEUA) at the University of Brasília, number 44568/2009. The study was carried out on a commercial farm with capacity to house 3,800 sows in a group-housed system and 6,900 in individual stalls, in Midwest of Brazil (Parallel $18^{\circ}$ ), a region with tropical climate, characterized by two distinct seasons, with rainy summers and dry winters, with average ambient temperatures varying from $13^{\circ}$ to $29^{\circ} \mathrm{C}$.

The three systems were present on the same farm. The females in collective pregnancies were in the same shed, while the dams reared in stalls were kept in other sheds. The evaluated data were extracted from the farm's operating system. Data that was three standard deviations above or below the mean were removed, as well as data on females that died before farrowing. Contemporary groups were formed, taking into consideration nutrition, insemination protocol, genetic group of the dam and climatic conditions. After weaning, dams returned to the Stalls, received a nutritional boost (flushing) and, when estrus was detected, they were inseminated. After insemination, they were allocated to collective groups (Pen5 or Pen42) or individual stalls (Stall), respecting the 
dynamics of the weekly batch-forming on the farm.

Females in the Stall group after insemination remained in the cages. There were females who participated in the three treatments in different reproductive cycles. The reproductive data of the females of each treatment were collected: Stall sows were maintained in individual cages throughout gestation; Pen5 - sows were transferred to the group-housing system within 3 to 5 days after the first insemination and maintained as a dynamic group, and Pen42 - sows were maintained in individual stalls until days 38 to 42 after the first insemination. Then they were transferred to the group-housing system and maintained as a dynamic group. The genetic groups on-farm were: DanBred25 (80\% of Pen5 and Pen42, 50\% Stall); DanBred90 (5\% Pen5 and Pen42, 30\% Stall) and Large White (15\% Pen5 and Pen $42 ; 20 \%$ Stall).

The females in the group-housed systems were reared in the same gestation and maternity building, while the females in the Stall system were reared in a separate building. The sows in group-housing systems were allocated in dynamic groups (with input and output of sows) with 80 sows each, until three days before the farrowing when the sows were moved to farrowing crates. The pens used in the group-housing systems were composed of a circulation area built with slatted floors and five sub-areas interconnected to the common area, with compact floors, which allowed the sows to hide. The density was $2.2 \mathrm{~m}^{2} / \mathrm{sow}$. In the Stall system the sow had a space of $0.65 \times 2.00 \mathrm{~m}$.

The sows were kept as a contemporary group with the same climatic condition, nutritional management, insemination protocol and semen quality. Sows received the same feed formulation with the same ingredients and storage forms. Feeding was provided in liquid form and the amount of feed received by each sow was calculated based on gestation time, body condition score and farrowing order. Sows kept in stalls were fed individually once per day $(08 \mathrm{~h} 00$ a.m.), while those kept in group-housing system were tagged with a microchip and automatically fed with an electronic sow feeder (ESF). The ESF system was kept on and the release of feed was triggered by a voluntary entrance of the animals until reaching its daily feed intake. In this system, females that did not feed for 48 hours were identified by the system, which allowed the handler to select them and direct them to the feeder.

The reproductive data of each female were evaluated individually for four years, except for the Pen5 system that was evaluated for three years. The results were compiled in two different ways. The first aimed to compare the productive results of the sows maintained in individual stalls (Stall) and group-housing (Pen42) systems. These data (weekly averages of female reproductive results) were collected based on the results of the weekly means of the reproductive parameters of the animals. A total of 209 weeks in each treatment (Stall and Pen42) were analyzed. The second analysis aimed to evaluate the effect of the type of group-housing in the reproductive parameters of the sows, evaluating sows grouphoused within 3 to 5 days after breeding (Pen5), sows group-housed within 38 to 42 days (Pen42) after breeding and sows maintained in individual stalls (Stall). These data were collected based on the individual parameters of sows.

The detection of heat was performed with the presence of the boar as well as the reflex of tolerance to the male. Females in heat were marked and inseminated 12 hours later. They received up to three doses of fresh semen, the first being performed 12 hours after the detection of heat, the second dose 12 hours after the first and the third dose, if the dam accepted, 12 hours after the second dose. The following reproductive parameters were analyzed.

In total, 848 reproductive cycles of Pen5, 5,547 cycles of Pen42 and 13,788 of the Stall systems were analyzed. There were no interferences in the management of the farms for the collection of the reproductive data. Therefore, routine practices such as the application of oxytocin in dystocic farrows or for the induction of delayed farrows were performed.

Statistical analysis was performed using SAS® version 9.3 (Statistical Analysis Institute, Cary, NC, USA). Data were tested for normality using Shapiro-Wilk test in PROC UNIVARIATE. Those that were not normal were transformed. For percentages, these were arcsin (square $\operatorname{root}(\mathrm{x})$ ) where $\mathrm{x}$ is the original variable. Counts were transformed using the square root (or square root 
+ constant) of the original number. Means are presented as retro-transformed where applicable. When this was not adequate PROC NPAR1WAY was used for Kruskal Wallis test to compare the treatments. The three systems (Stall, Pen5 and Pen42) were compared using the PROC MIXED procedure considering the system, genetic group, year, farrowing time, farrowing type, season, sows' age, sow and employees as classificatory variables.

Table 1: Description and analyzes used to evaluate reproductive parameters of sows.

\begin{tabular}{|c|c|c|}
\hline Reproductive parameter & Description & Analysis \\
\hline Return to estrous & $\%$ of sows that returned to estrous & MIXED \\
\hline Abortion & $\%$ of pregnant sows that aborted & MIXED \\
\hline Gestation length & $\begin{array}{l}\text { Average length of gestation in days, from the } \\
\text { date of first insemination }\end{array}$ & MIXED \\
\hline Duration of farrowing & Duration of farrowing in hours & MIXED \\
\hline Farrowing rate & $\%$ of sows farrowed & MIXED \\
\hline Farrowing type ${ }^{1}$ & $\begin{array}{l}\text { Frequency of premature, normal, induced, or } \\
\text { dystocic farrowing }\end{array}$ & LOGISTIC \\
\hline Total piglets born & $\begin{array}{l}\text { Number of piglets born per sow, including live, } \\
\text { dead at birth and stillbirths and mummified } \\
\text { piglets }\end{array}$ & MIXED \\
\hline Average litter weight & Average weight $(\mathrm{kg})$ of litter at birth & MIXED \\
\hline Birth weight & Mean weight $(\mathrm{kg})$ of the piglets at birth & MIXED \\
\hline Death at birth & $\%$ of dead piglets up to a few hours after birth & MIXED \\
\hline Mummified & $\%$ of mummified piglets per sow; & MIXED \\
\hline Piglets born alive & Number of piglets born alive per sow & MIXED \\
\hline Stillbirths & Number piglets already dead in the birth canal. & NPAR1WAY \\
\hline Total weaned & Number of piglets weaned per sow & MIXED \\
\hline Low-viability piglets & $\%$ of piglets born under 500 grams or very weak & MIXED \\
\hline Death at weaning & $\%$ of dead piglets per sow until weaning & MIXED \\
\hline Weaning weight & Average weight $(\mathrm{kg})$ of piglets at weaning & MIXED \\
\hline $\begin{array}{l}\text { Number of piglets weaned per } \\
\text { sow per year }\end{array}$ & $\begin{array}{l}\text { Productive index of the sows used in the } \\
\text { experiment }\end{array}$ & MIXED \\
\hline Farrowing/sow/ year & Mean number of farrowing per sow per year & FREQ/Chisq \\
\hline
\end{tabular}

${ }^{1}$ As over $99 \%$ of farrowing were normal or dystocic, all other types were classified as dystocic.

For death at birth and low-viability piglets, the non-skewed least variance (MIVQUEO) quadratic estimation method was used. For average litter weight and the birth weight of the piglets as dependent variables, the PROC MIXED was associated with the likelihood method (ML). Description and analyzes used to evaluate reproductive parameters of sows were detailed in table 1 . In all analyzes, the sows were considered as repeated measures. Genetic group was not significant and therefore removed from all models. All means were adjusted by least squares method (LSMEANS). For comparison of means, the Tukey-Kramer test was used with $5 \%$ probability $(\mathrm{P}<0.05)$.

\section{RESULTS}

Reproductive parameters such as return to estrous (3.32\%), abortion $(1.03 \%)$, farrowing per sow per year (2.43) and number of mummified piglets $(2.53 \%)$ were the same for sows in individual stalls (Stall) and group-housed within 38 to 42 days after breeding (Pen42) systems. However, sows in Pen42 system had higher number of piglets weaned per sow per year (31.78 versus 29.70), total weaned (12.84 versus12.20), total piglets born (15.63 versus 15.23), piglets born alive (14.01 versus 13.52), farrowing rate (92.61 versus $91.73 \%$ ), weaning weight (6.43 versus $5.70 \mathrm{~kg}$ ), and lower stillbirths (6.91 versus $7.41 \%$ ), birth weight $(1.35$ versus $1.38 \mathrm{~kg})$ and death at weaning (6.82 versus 9.96) than in the Stall system (Table 2). 
Birth weight (1.45 and 1.43 versus $1.48 \mathrm{~kg}$ ) was higher for sows in Stall system, however the piglets born alive (12.63 and 12.54 versus 11.70), total piglets born (14.19 and 14.97 versus 14.88), average litter weight (16.37 and 17.25 versus $16.85 \mathrm{~kg})$ and duration of farrowing $(08 \mathrm{~h} 08$ and 09 h09 versus $08 \mathrm{~h} 42$ ) were lower in this system than in group-housed within 3 to 5 days after breeding (Pen5) and Pen42 systems, respectively. There was no difference between Pen5 and Stall systems for mummified $(0.26$ and $0.30 \%)$ and gestation period $(114.55$ and $114.57 \mathrm{~d})$, respectively.

Table 2. Reproductive parameters of sows according to the housing system during gestation

\begin{tabular}{lccc}
\hline \multirow{2}{*}{ Reproductive parameter } & \multicolumn{2}{c}{ Housing system $^{1}$} & \multirow{2}{*}{ Pr $>\mathrm{F}$} \\
\cline { 2 - 3 } & $3.47 \pm 2.75$ & Pen 42 & 0.2542 \\
Return to estrous, \% & $1.04 \pm 1.43$ & $3.16 \pm 2.85$ & 0.9613 \\
Abortion, \% & $29.70 \pm 2.49$ & $1.03 \pm 1.55$ & $<0.0001$ \\
Piglets weaned per sow per year & $12.20 \pm 1.01$ & $31.78 \pm 2.47$ & $<0.0001$ \\
Total weaned & $2.43 \pm 0.07$ & $12.84 \pm 1.46$ & 0.5631 \\
Farrowing per sow per year & $2.77 \pm 1.01$ & $2.44 \pm 0.08$ & 0.0550 \\
Mummified, \% & $7.41 \pm 2.61$ & $2.93 \pm 1.12$ & 0.0013 \\
Stillbirths, \% & $15.23 \pm 0.74$ & $6.91 \pm 1.89$ & $<0.0001$ \\
Total piglets born & $13.52 \pm 0.70$ & $15.63 \pm 0.83$ & $<0.0001$ \\
Piglets born alive & $1.38 \pm 0.07$ & $14.01 \pm 0.72$ & $<0.0001$ \\
Birth weight, kg & $91.73 \pm 3.90$ & $1.35 \pm 0.04$ & 0.0070 \\
Farrowing rate, $\%$ & $9.96 \pm 2.25$ & $92.61 \pm 3.46$ & $<0.0001$ \\
Death at weaning & $5.70 \pm 0.50$ & $6.82 \pm 5.52$ & $<0.0001$ \\
Weaning weight, kg & $6.43 \pm 0.44$ & . \\
\hline
\end{tabular}

Stall: individual stalls; Pen42: group-housed within 38 to 42 days after breeding; Pr>F: probability.

${ }^{1}$ Analysis of 209 weeks per treatment. Means performed by averages of weekly reproductive parameters.

The Pen42 system had a higher percentage of mummified piglets $(0.41$ versus 0.26 and $0.30 \%)$ and a shorter gestation length (114.22 versus 114.55 and $114.57 \mathrm{~d}$ ), when compared Pen5 and Stall systems respectively, and similar results to Pen5 system for piglets born alive (13.54 and
16.63), stillbirths (2.15 and 2.16), total piglets born (14.88 and 14.97), average litter weight (16.85 and $17.25 \mathrm{~kg}$ ), birth weight (1.43 and $1.45 \mathrm{~kg})$. All groups differed for duration of farrowing $(\mathrm{P}<0.0001)$ with the least time for females in Stall system (Table 3).

Table 3. Reproductive parameters of sows according to the housing system during gestation

\begin{tabular}{lcccc}
\hline \multirow{2}{*}{ Reproductive parameter } & \multicolumn{3}{c}{ Housing system } & Pr $>\mathrm{F}$ \\
\cline { 2 - 4 } & $\begin{array}{c}\text { Pen5 } \\
(848 \text { cycles })\end{array}$ & $\begin{array}{c}\text { Pen42 } \\
(5.547 \text { cycles })\end{array}$ & $\begin{array}{c}\text { Stall } \\
(13.788 \text { cycles })\end{array}$ & \\
\hline Piglets born alive, $\mathrm{n}$ & $12.63 \pm 3.43 \mathrm{a}$ & $12.54 \pm 3.47 \mathrm{a}$ & $11.70 \pm 3.47 \mathrm{~b}$ & $<0.0001$ \\
Stillbirths, \% & $2.16 \pm 1.44 \mathrm{~b}$ & $2.15 \pm 1.50 \mathrm{~b}$ & $2.42 \pm 1.53 \mathrm{a}$ & $<0.0001$ \\
Death at birth, \% & $0.12 \pm 0.57 \mathrm{ab}$ & $0.13 \pm 0.45 \mathrm{a}$ & $0.10 \pm 0.47 \mathrm{~b}$ & $<0.0001$ \\
Mummified, \% & $0.26 \pm 0.89 \mathrm{~b}$ & $0.41 \pm 0.93 \mathrm{a}$ & $0.30 \pm 0.90 \mathrm{~b}$ & $<0.0001$ \\
Total piglets born, $\mathrm{n}$ & $14.97 \pm 3.57 \mathrm{a}$ & $14.88 \pm 3.60 \mathrm{a}$ & $14.19 \pm 3.63 \mathrm{~b}$ & $<0.0001$ \\
Average litter weight, kg & $17.25 \pm 4.50 \mathrm{a}$ & $16.85 \pm 4.38 \mathrm{a}$ & $16.37 \pm 4.33 \mathrm{~b}$ & $<0.0001$ \\
Birth weight, kg & $1.45 \pm 0.25 \mathrm{~b}$ & $1.43 \pm 0.26 \mathrm{~b}$ & $1.48 \pm 0.26 \mathrm{a}$ & $<0.0500$ \\
Low-viability piglets, $\mathrm{n}$ & $0.006 \pm 0.18 \mathrm{ab}$ & $0.020 \pm 0.19 \mathrm{a}$ & $0.007 \pm 0.16 \mathrm{~b}$ & $<0.0001$ \\
Duration of farrowing, $\mathrm{h}$ & $06 \mathrm{~h} 06 \pm 0 \mathrm{~h} 00 \mathrm{a}$ & $05 \mathrm{~h} 36 \pm 03 \mathrm{~h} 17 \mathrm{~b}$ & $05 \mathrm{~h} 10 \pm 03 \mathrm{~h} 31 \mathrm{c}$ & $<0.0001$ \\
Gestation length, d & $114.55 \pm 1.48 \mathrm{a}$ & $114.22 \pm 1.47 \mathrm{~b}$ & $114.57 \pm 1.44 \mathrm{a}$ & $<0.0001$ \\
\hline
\end{tabular}

Pen5: group-housed within 3 to 5 days after breeding; Pen42: group-housed within 38 to 42 days after breeding; Stall: individual stalls; Pr $>$ F: probability; Death at birth: percentage of dead piglets few hours after birth; Stillbirths: piglets that are already dead in the birth canal; n: number. Means with different letters in the same row differ statistically by Tukey test $(\mathrm{P}<0.05)$. 
The number of dystocic farrowing was higher in the Stall system $(35.57 \%)$ than in Pen5 $(28.22 \%)$ and Pen42 $(20.67 \%)$ systems $(\mathrm{P}<0.0001)$. The higher frequencies of normal farrowing were observed for sows group housed (Pen5 (71.66\%) and Pen42 $(78.90 \%))$ than in the Stall $(64.19 \%)$ system $(\mathrm{P}<0.0001)$.

\section{DISCUSSION}

The shorter duration of farrowing observed for the sows in the individual stalls may be due to the lack of a need for adaptation to a new housing condition that was present for group-housed sows, since they were already housed individually. Sows managed in group-housing system passed through a period of stress until the adaptation to the individual condition. Also, this adaptation period is very short, only three days or less from the date of farrowing, leading to stress, which may increase the duration of farrowing. The same was observed by Yuna et al. (2015) who reported that non-crated sows that were moved to individual stalls before farrowing tended to have a longer duration of farrowing than sows crated prepartum. They also reported that non-crated sows tended to remain more time standing and moving in the farrowing crate when compared with those crated prepartum, suggesting greater discomfort of these sows, possibly due to additional stress induced by sudden confinement.

In the present study, the number of piglets born alive and total piglets born was higher in sows reared in group-housed systems (Pen5 and Pen42). Maternities for group-housed systems (Pen5 and Pen42) were different from Stall system, as they were larger and had ventilation systems. Magesth et al. (2019) observed that the types of facilities in the maternity do not affect the number of piglets born alive and the total number of births, only affected the postpartum mortality. Housing system, environment, nutritional management and social interactions may change the level of circulating cortisol in pregnant sows. Environment and nutritional management were the same in three treatments.

The housing systems and social interactions differed due to the research objective itself. Sows kept in cages have more difficulty in having either positive or negative social interactions, despite the fact that they can occur, and this leads to stress due to the deprivation of important behavior for the species (positive social) or due to the difficulty to escape the aggressions of females at their side. The chronic stress of the sows in individual stalls may be an explanation for the lower number of piglets born alive and total piglets born in the Stall system. Hulbert and McGlone (2006) observed that reproductive performance was affected by severe stress, mainly reducing litter size. The high levels of cortisol oscillation interfere with the release of gonadotrophins, which may lead to infertility or decrease the reproductive performance of the sows (Melchior et al., 2012). Sows group-housed during pregnancy have stress peaks, which are soon diminished. After the establishment of the hierarchy, the social interactions decrease, thus reducing the level of cortisol (Anil et al., 2006), which decreases the effect of stress on the reproductive performance of these sows.

The largest number of mummified fetuses observed in the Pen42 system was associated with the time when animals were grouped, and the higher number of total piglets born in this system. Normally these sows are kept in individual stalls during 38 to 42 days of gestation and then grouphoused in pens with up to 80 females. The adverse social interaction that occurs in this period can cause the death of some fetuses, which then can mummify. In the Pen5 system this effect was not observed because the sows were grouped at the beginning of gestation, so the embryo would be absorbed, since bone formation had not yet occurred. Embryo bone formation begins with 30 to 40 days (Pescador et al., 2010) and ends with 70 to 100 days of gestation (Mengeling et al., 2000), so grouping sows in this period may lead to more mummified fetuses.

The lack of uterine space, due to increased litter size in prolific females, is also reported as a possible cause of fetal death (Koketsu et al., 2017). A percentage of up to $1.5 \%$ of mummified fetuses within a farm is considered normal (Borges et al., 2005). The three gestation systems evaluated in the present study showed normal percentage $(0.41 \%, 0.30$ and 0.26 for Pen 42 , Stall and Pen5, respectively) of mummified fetuses.

Death at birth was more frequent in sows with induced and premature farrowing. The sows group-housed within 38 to 42 days after breeding (Pen42) had higher frequency of premature farrowing than the sows in the Stall and Pen5 
systems, which may have led to a greater number of deaths at birth in the Pen42 system. This may be due the fact that sows maintained in collective systems tend to change position and move more in the farrowing crates (Boyle et al., 2002; Yuna et al., 2015), which increases the probability of piglet crushing and delay to first nursing, leaving the piglets lethargic and weak.

Moreover, the lower number of deaths at birth in the Stall system could be due to the lower number of piglets born alive and higher birth weight which led to fewer teat disputes during nursing. Therefore, the piglets were able to ingest greater amount of colostrum, making them more active and stronger, which reduced the chance of piglet crushing.

Stillbirths are major problem in commercial pig farming. The higher number of stillbirths in the Stall system could be associated with the lower frequency of normal farrowing. To reduce mortality rates during birth, drugs are frequently used to reduce the duration of farrowing (Hass et $a l ., 2017)$. Farrowing induction is performed with the application of oxytocin that reduces the expulsion interval between one piglet and another and decrease the time of farrowing of the sows (Mota-Rojas et al., 2005; González-Lozano et al., 2010). The lack of training on the correct time to use oxytocin and misuse of oxytocin in farrowing induction increases the chance of stillbirths, due to intensification of the uterine muscular contraction causing intrauterine hypoxia (Kaeoket, 2006; Mota-Rojas et al., 2006). Studies have shown that misuse of oxytocin induction could lead to negative effects such as a significant increase in the number of stillbirths per litter and umbilical cord bleeding and rupture (Mota-Rojas et al., 2002; 2005; Kaeoket, 2006; Mota-Rojas et al., 2006). Kirkden et al. (2013) reported no effect of oxytocin on increasing the rate of stillbirths but concluded that the application increased dystocic farrowing and this was directly related to the increase in stillbirths per litter.

The greater number of piglets born alive and the lower mortality rate until weaning led to a greater number of piglets weaned in the collective groups. The number of weaned females in the Pen 42 when compared to the Stall may have been influenced by the quality of the maternity of the collective systems that had a cooling system for the dams in the heat season, leaving them less agitated and consequently less crushed or bruised piglets. This data is confirmed by the death rate until weaning, which for Stall was 9.96 piglets and at Pen42 6.82 piglets. The teams of the two maternity hospitals received the same training to assist in farrowing and care for the piglets and, therefore, the humananimal interaction did not influence the results obtained. The quality of the maternity brings greater weight gain and lower mortality of piglets at birth, according to Magesh et al. (2019), which increases the profit of the farm and decreases the production cost per kilogram of live weight of piglets.

Group-housing sows in collective pens 3 to 5 days after breeding (Pen5) did not affect the reproductive performance of sows and some results were improved compared to the Pen42 system. Studies carried out in humans reported that mothers with low levels of physical activity were more likely to have instrumental delivery (including forceps, suction cups, elective, induced and emergency cesarean sections) compared to mothers with higher levels of physical activity (Morgan et al., 2015).

These authors also suggested that the type of delivery was associated with the level of maternal physical activity and not with the body mass index (BMI). As individual stalled (Stall) sows were deprived of exercise throughout the gestational period this may be one of the possible causes of the high index of dystocic farrowing. Other studies with pregnant women have reported that both lack of physical exercise during pregnancy and excessive exercise can be detrimental to the mother and baby as regards fetal birth weight, duration of delivery, prematurity, and type of delivery (cesarean or normal) (Jean and HaySmith, 2013), which may explain the best frequency of normal farrowing found in sows reared in the Pen42 than the Pen5 system.

In the present study, sows in the Pen5 system were influenced by the input and output of sows in nonregular time intervals when compared to the females maintained in Pen42 system, since they were kept in dynamic groups. Thus, hierarchy disputes and frequent fights occurred with greater intensity in this system (Pen5), causing higher levels of physical activity which explains the lower rates of normal farrowing and longer duration of farrowing. On the other hand, Stall sows were deprived of physical activity 
increasing the frequency of dystocic farrowing, but farrowing duration was shorter than those observed in Pen42 and Pen5 systems.

\section{CONCLUSION}

The types of housing system during pregnancy influence the farm's reproductive indexes, with the collective systems showing a significant increase in the number of piglets born alive, total piglets born and average weight of the litter. An investment only in the type of housing during pregnancy guarantees good reproductive rates of the females, but it is not enough to guarantee a good performance of the piglet after birth. Investments in maternity wards with good thermal comfort, ventilation and side protection for the piglets are necessary. Sows can be group-housed within 3-5 days after breeding without increasing the number of stillbirths, return to estrous, death at birth and mummified fetus. Therefore, the complete removal of individual stalls may be a safe indication for commercial farms, since the group-housed within 3 to 5 days after breeding system has shown to be as effective as individual stalls and do not adversely affect reproductive parameters.

\section{ACKNOWLEDGEMENTS}

The authors thank Coordenação de Aperfeiçoamento de Pessoal de Nível Superior CAPES (Brazil) for financial support and scholarships.

\section{REFERENCES}

ALVARENGA，A.L.N.; CHIARINI-GARCIA, H.; CARDEAL, P.C. et al. Intra-uterine growth retardation affects birth weight and post natal development in pigs, impairing muscle accretion, duodenal mucosa morphology and carcass traits. Reprod. Fertil. Dev., v.25, p.387-395, 2013.

ANIL, L.; ANIL, S.S.; DEEN, J. et al. Effect of group size and structure on the welfare and performance of pregnant sows in pens with electronic sow feeders. Can. J. Vet. Res., v.70, p.128-136, 2006.

BORGES, V.F.; BERNARDI, M.L.; BORTOLOZZO, F.P.; WENTZ, I. Risk factors for stillbirth and foetal mummification in four Brazilian swine herds. Prev. Vet. Med., v.70, p.165-176, 2005.
BOYLE, L.A.; LYNCH, F.C.; BOYLE, P.B. et al. Effect of gestation housing on behaviour and skin lesions of sows in farrowing crates. Appl. Anim. Behav. Sci., v.76, p.119-134, 2002.

DRON, N.; HÉRMANDEZ-JOVER, M.; DOYLE, R.E.; HOLYOAKE, P.K. Investigating risk factors and possible infectious aetiologies of mummified fetuses on a large piggery in Australia. Aust. Vet. J., v.92, p.472-478, 2014.

GONZÁLEZ-LOZANO, M.; TRUJILLOORTEGA, M. E.; BECERRIL-HERRERA, M. et $a l$. Uterine activity and fetal electronic monitoring in parturient sows treated with vetrabutin chlorhydrate. J. Vet. Pharmacol. Therap. v.33, p.28-34, 2010.

HASS, C.S.; SANTOS, M.Q.; ROVANI, M.T. et al. Prepartum progestagen supplementation in swine: a strategy to facilitate piglet care and prevent early parturition. Cien. Rural, v.47, p.e20170380, 2017.

HULBERT, L.E.; McGLONE, J.J. Evaluation of drop versus trickle -feeding systems for crated or group - penned gestating sows. J. Anim. Sci., v.84, p.1004-1014, 2006.

JEAN, N.; HAY-SMITH, C. Maternity exercises 75 years on: what has changed and what does experimental evidence tell us? N.Z.J. Psychiatr., v.41, p.16-19, 2013.

KAEOKET, K. The effect of dose and route of administration of R-cloprostenol on the parturient response of sows. Reprod. Domest. Anim., v.41, p.472-476, 2006.

KIRKDEN, R.D.; BROOM, D.M.; ANDERSEN, I.L. Piglet mortality: The impact of induction of farrowing using prostaglandins and oxytocin. Anim. Reprod. Sci., v.138, p.14-24, 2013.

KNOX, R.; SALAK-JOHNSON, J.; HOPGOOD, M.; GREINER, L. Effect of day of mixing gestating sows on measures of reproductive performance and animal welfare. J. Anim. Sci., v.92, p.1698-1707, 2014.

KOKETSU, Y.; TANI, S.; LIDA, R. Factors for improving reproductive performance of sows and herd productivity in commercial breeding herds. Porc. Health Manag., v.3, p.1-10, 2017.

KRANENDONK, G.; VAN DER MHEEN, H.; FILLERUP, M.; HOPSTER, H. Social rank of pregnant sows affects their body weight gain and 
behavior and performance of offspring. J. Anim. Sci., v.85, p.420-429, 2007.

MAGESH, R.D.; KANNAN, A.; SHERIN, K.G. et al. Litter performance of Large White Yorkshire sows raised in different farrowing house systems in tropical climate. J. Anim. Res., v.9, p.119-123, 2019.

MELCHIOR, R.; ZANELLA, I.; LOVATTO P.A. et al. Meta-analysis on the relationship among feeding characteristics, salivary and plasmatic cortisol levels, and performance of pregnant sows housed in different systems. Livest. Sci., v.150, p.310-315, 2012.

MENGELING, W.L.; LAGER, K.M.; VOWALD, A.C. The effect of porcine parvovirus and respiratory syndrome virus on porcine reproductive performance. Anim. Reprod. Sci., v.60-61, p.199-210, 2000.

MORGAN, K.L.; RAHMAN, M.A.; HILL, R.A. et al. Physical activity and excess weight in pregnancy have independent and unique effects on delivery and perinatal outcomes. Plos One., v.9, p.e94532, 2015.

MOTA-ROJAS, D.; TRUJILLO-ORTEGA, E.T.; VILLANUEVA-GARCIA, D. et al. Can Uterotonics Reduce Fetal and Newborn Piglet Mortality by Perinatal Asphyxia and Improve Functional Vitality?. J. Med. Sci., v.6, p.884-893, 2006.

MOTA-ROJAS, D.; MARTÍNEZ-BURNES J.; TRUJILLO, M.E. et al. Uterine and fetal asphyxia monitoring in parturient sows treated with oxytocin. Anim. Reprod. Sci., v.86, p.131-141, 2005.

MOTA-ROJAS, D; MARTINEZ-BURNES, J.; TRUJILLO-ORTEGA, M.E. et al. Effect of oxytocin treatment in sows on umbilical cord morphology, meconium staining, and neonatal mortality of piglets. Am. J. Vet. Res., v.63, p.15711574, 2002.
PANDORFI, H.; SILVA, I.J.O.; SARNIGHAUSEN, V.C.R. et al. Use of artificial neural networks on the prediction of zootechnical indexes on gestation and farrowing stages of swines. Rev. Bras. Zootec., v.40, p.676-681, 2011.

PESCADOR, C.A.; BANDARRA, P.M.; ANTONIASSI, N.A.B. et al. Metodologia aplicada na avaliação de fetos suínos abortados e natimortos. Pesqui. Vet. Bras., v.30, p.1058-1063, 2010.

SALAK-JOHNSON, J.L. Social status and housing factors affect reproductive performance of pregnant sows in groups. Mol. Reprod. Dev., v.84, p.905-913, 2017.

STEVENS, B.; KARLEN, G.M.; MORRISON, R. et al. Effects of stage of gestation at mixing on aggression, injuries and stress in sows. Appl. Anim. Behav. Sci., v.165, p.40-46, 2015.

THE Council of the European Union. Council Directive 2008/120/EC of 18 December 2008: laying down minimum standards for the protection of pigs. Official Journal of the European Union, 2009. Available in: $<$ http://eurlex.europa.eu/LexUriServ/LexUri Serv.do?uri=OJ:L:2009:047:0005:0013:EN:PDF. Accessed in: 08 Jan. 2019.

VAN WETTERE, W.H.E.J.; PAIN, S.J.; STOTT, P.G.; HUGHES, P.E. Mixing gilts in early pregnancy does not affect embryo survival. Anim. Reprod. Sci., v.104, p.382-388, 2008.

YUNA J.; SWANA, K.M.; OLIVIERO, C. et al. Effects of prepartum housing environment on abnormal behaviour, the farrowing process, and interactions with circulating oxytocin in sows. Appl. Anim. Behav. Sci., v.162, p.20-25, 2015. 